\title{
The Cognitive Structures of Turkish Pre-servise Teachers in Relation to the Concept of Light
}

\author{
Gunay Palic Sadoglu \\ Faculty of Education, Recep Tayyip Erdogan University, Turkey
}

Copyright $(2016$ by authors, all rights reserved. Authors agree that this article remains permanently open access under the terms of the Creative Commons Attribution License 4.0 International License

\begin{abstract}
As learning is a product of the interaction between certain concepts which are already present within an individual's mind, it is becoming increasingly important to determine the cognitive structures in relation to these concepts which are present within the minds of students. It has been said that the word association test, which is a technique that discloses the cognitive structure, provides an opportunity to evaluate the structure of connections between the creations of knowledge within the minds of individuals. This also includes the question as to whether these connections are considered logical or not. The goal of this study is to examine the cognitive structures of primary school Turkish pre-service teachers in regards to the concept of light. This also happens to be one of the basic concepts of science, by means of the word association test. The sample group within this qualitative research study was comprised of 35 pre-service teachers, who were all in the process of studying at the 3rd grade in the Department of Primary Education. The sentences formed by each of the pre-service teachers in regards to the concept of light were evaluated in terms of the categories developed by Ozata-Yucel \& Ozkan (2015). Whilst the pre-service teachers generally associated the concept of light to the concepts of the sun, stars, light bulb, illumination, energy, light refraction, velocity of light, artificial light source, linear road, electricity, lamp and the moon, it was determined that the concept of light was to be related to the individual source and nature of light.
\end{abstract}

Keywords The Cognitive Structures, The Word Association Test, Turkish Pre-service Teachers, Light

\section{Introduction}

Due to the fact that learning is a product of the interaction between certain concepts which are already present within an individual's mind, it is becoming increasingly important to determine the cognitive structures in relation to these concepts which are present within the minds of students. Shavelson [49] (1974) defines the cognitive structure as a hypothetical structure which involves the organization of concepts and their relation between the minds. Tsai [54] (2001) also emphasizes the fact that the cognitive structure, which contains the available knowledge and experiences of the learning individual, has an effect on the reconfiguration and acquisition of knowledge from incoming stimuli. Therefore, determining the cognitive structures of students in regard to certain concepts will assist the teachers. The teachers will guide the students through the formation of correlations between their available and newly acquired knowledge to select the appropriate teaching strategy [55]. If this is achieved, the students' academic success will increase and they will begin to evaluate their success within the exploration of their cognitive structures [55].

It can also be said that the conducted studies which involve the identification of cognitive structures within students, have a significant role in terms of deriving meaningful information about them. However, it has been noted that revealing the cognitive structures of each individual is quite difficult, hindering the possibility to describe the cognitive structures within the scope of their thoughts about the key concepts $[18,19]$. The word association test is considered to be one of the techniques which enable the evaluation of knowledge networking. By connecting structures between each of the concepts which create the knowledge network, it is possible to determine whether or not those connections are meaningful within the scope of key concepts $[3,4]$. The word association test is one of the techniques which have implemented the evaluation of conceptual structures, besides its use in identifying psychological and sociological beliefs and attitudes [23]. Moreover, the word association test is of benefit as a tool, used to reveal scientific conceptual structures [30, 31].

In literature, word association tests were implemented in relation to various learning fields in order to reveal cognitive structures $[2,3,11,13,14,15,16,27,28,32,33,34,35,41$, $42,43,50,52,53]$, to identify misconceptions $[4,16,28,42$, $50]$, to reveal conceptual alterations $[7,8,16,37,39]$, to determine the effect on readiness [21], to determine perceptions [17], and to determine the level of conceptual correlation $[29,40]$ of students. Despite the fact that a large 
portion of these studies were conducted in the field of science education (ecology, environment and environmental issues, immunity, discharge, virus, aids, enzyme, biological variety, fundamental compounds of live organisms, osmosis, ecosystem ecology, collision theory, Le Chatelier's principle, equilibrium, dissolution, electrochemistry, solar system and space, electron-proton-neutron, force and movement, nature of science, definition and modification of substance, etc.), it is believed that studies which intend to determine the cognitive structures related to the concept of light by means of the word association test are very limited.

It is especially vital for students to perceive and utilize the concept of light correctly, which is related to our daily life and multiple disciplines. It has been observed that a number of studies are therefore performed in relation to how students perceive and understand the concept of light, being one of the fundamental concepts of science. It has also been observed that these conducted studies aim to reveal the different levels of understanding amongst students of various education stages with regard to the concepts and their misconceptions $[1,6,9,10,20,25,26,45,48,51,56,57,58$, $60]$. Thanks to this study, it has been discovered that the students have adopted many misconceptions and various alternative concepts.

Guesne, Driver \& Tiberghien [20] (1985) found in their study, which was conducted with 13-14 year old students, that they generally perceive light as a substance. Ramadas \& Driver [45] (1989) found that many students define light as "long, thin flashing lines", expressing that the inability to observe the direction of the light created difficulties for the students to "express the presence of light". Cansungu [9] (2000) determined that primary school students had misconceptions of light and their daily life experiences contributed to the formation of these misconceptions. Yildiz [60] (2000) found in his study that primary school students in the 6th grade held the misconception that "light is an illuminating substance or object", "light is an effect that enables us to see" and "light is same as illumination". Akdeniz, Yildiz \& Yigit [1] (2001) also found in a study that $70 \%$ of 6 th grade primary school students had difficulties in understanding and explaining the concept of defining light, the diffusion of light, the reflection of light and the refraction of light, along with $30 \%$ of these students holding misconceptions about these concepts. Buyukkasap, Duzgun \& Ertugrul [6] (2001) stated that high school students held the misconceptions that "light disperses to various distances depending on daytime and nighttime", "light does not disperse during daytime", "light does not disperse during nighttime", "light has different speeds depending on its source" and "looking is sufficient to be able to see". Cansungu- Koray \& Bal [10] (2002) found in their study that 5th and 6th grade students also have misconceptions as follows: "light is a source that illumines the environment", "light is the energy distributed by light sources into their environment" and "a type of electricity source that enables us to see the environment". Sen [48] (2003) noticed in a study that a majority of primary school students believe that "light is an object that fills the atmosphere"; however, "it can move with a finite velocity when affected from the environment". Unal-Coban [56] (2009) pointed that 7th grade students hold the ideas that "light does not move in darkness", "white light has no color", "all kinds of light are visible to human eye", "the sky appears blue due to the reflection of light from the ocean", "velocity of light is the same in all environments", "prism gives the light colors", "when observed through a clear substance, an object seems to remain in place" and the "lenses that enlarge objects also enlarge the light". Kara, Erduran-Avci \& Cekbas [25] (2008) found in their study that the majority of science pre-service teachers have a significant amount of limited knowledge on light, and they have misconceptions about it. Kaya [26] (2010) indicated that the group of science pre-service teachers have such misunderstandings as" light is a substance that illumines the surface it reaches", "light is a set of lines that emanate from a certain source and go into infinity", which proves that their level of knowledge in regards to light is quite limited. Uzoglu, Yildiz, Demir \& Buyukkasap [57] (2013) found that each of the science pre-service teachers adopted the alternative concepts of "a white cat will be visible in the dark" and that "stars are not visible during daytime because they only reflect the moonlight". Tasdemir \& Demirbas [51] (2010) detected about the concept of light that students from primary education to university are more successful in understanding the concept of a clear substance.

The information of students gained in the learning environment depends on their prior knowledge and the contribution of learning environment. It is important to determine the students' prior knowledge to teach the right concept. This situation can contribute for meaningful and permanent learning. In this sense, the researches of cognitive structures are quite important point to realize successful learning. Cognitive structure researches provide teachers to know the background of students and to design appropriate teaching strategies, to use appropriate learning methods and tools with their students and to assist students to combine their past experience with new knowledge [37, 42]. Moreover, it has been noted that the process of accepting to learn a concept aids in the ability to learn more about the subject. In addition, it has been observed that students create conceptual structures that are logical to their own cognitive structures, but have little relation to scientific knowledge [35]. At this point, the cognitive structures of the students can be identified by means of the independent word association test, allowing alternative concepts to be revealed. The goal of this study is to determine how each of the pre-service teachers structures the concept of light within their minds, by means of the independent word association test and to reveal their scientific validity.

\section{Method}

This study adopts the qualitative research method. A qualitative research is a procedure which implements 
qualitative data gathering techniques such as observation, interview and document analysis, in an attempt to reveal the perceptions and events which occur within a natural environment in a realistic and holistic manner [61]. A total of 35 the Turkish pre-service teachers from the 3 rd grade of the Department of Primary Education participated in this study.

\subsection{Data Gathering Tools}

This study implements the independent word association test as a data collection tool. Word association, also known as associative experiment is a test, consisting of a list of words, administered to the respondent, who has to answer to each word by means of the first word coming to his or her mind [30]. The technique of word association was employed to measure the relatedness between concepts that are involved in learning [36]. The word association test is an alternative measuring and evaluation technique, which enables us to determine whether concepts form relations within long term memory and whether these relations are meaningful. This provides the opportunity to observe the knowledge network created within the mind, as well as the cognitive structures of each student and the relations which comprise this structure [3]. This technique relies on the presumption that each of the responses is solely given in relation to the stimulant word, without the limitation of thoughts which appear in mind [3, 30, 47].

The word association test requires responses that are not restricted to any specific category or class of words [31]. During the word association test, each of the students is asked to write down the concepts which are triggered in their mind, in regards to the key concept which is given during a certain period of time (generally 30 seconds). It is presumed that the sequential responses provided by the students from their long term memory in regards to the key concept reveal the connections formed within their cognitive structure, which exhibits a meaningful proximity. According to the meaningful proximity or meaningful distance effect, the proximity of two concepts within the meaningful memory defines the closeness of their relation. In saying this, during the recollection, the cognitive research will be performed faster and a response to any of the two concepts will be provided at a faster rate [4].

During this study, each of the pre-service teachers was asked to complete the independent word association test. In this test, the concept of light was presented as a stimulating word in the following format.

Light -1 :

Light -2 :

Light -3 :

Light -4 :

Light -5 :

Light -6 :

Light -7 :

Light -8 :

Light -9 :

Light -10 .
Sentence -1 :

Sentence -2 :

Sentence -3 :

The word association test consists of 2 stages. During the first stage of the independent word association test, the participants were asked to write down the concepts which were evoked by the stimulant word during a certain period of time [22]. The primary school pre-service teachers were asked to write down the first ten words that came to their minds in 30 seconds, in relation to the concept of light. However, by writing each key concept under the other prevents the chain response risk. If the student does not return to the key concept when writing down their answers, it could result in them writing words which are evoked by a response, rather than the key concept. During the second stage of the test, the participants were requested to write down 3 sentences relating to the given key concept in 30 seconds, this was then to be evaluated separately during the data analysis stage. Due to the response sentence relating to the key concept, it could alter the association, leaving no meaningful relation to the key concept in the individual's memory. Likewise, since the respective sentence could have a more complex and superior structure than a single word, the question as to whether it is scientific or not, or contains various misconceptions could affect the evaluation process.

\subsection{Data Analysis}

The data was analyzed by the content analysis method. The main goal of content analysis is to reach the concepts and relations that will be able to explain the data gathered. For this purpose, the gathered data firstly needs to be conceptualized then logically organized in accordance with the respective concepts and lastly the themes defining the data need to be identified [61].

All responses given to the key concepts were thoroughly examined. A frequency table was created in order to reveal which words or concepts were given in response to which key concept, with how many repetitions. The words that seemed unrelated were not taken into evaluation.

The sentences provided by the pre-service teachers in relation to the concept of light were examined individually and categorized in accordance with their contents. When categorizing the sentences, the categories developed by Ozata-Yucel \& Ozkan [42] (2015) were taken into consideration. The sentences submitted by the pre-service teachers were categorized in terms of correct scientific information, affective information, superficial information or information containing examples from daily life, non-scientific or misconceptual information. According to Ozata-Yucel \& Ozkan [42] (2015), if the sentences given by participants were correct in scientific terms, then they were placed into the correct scientific information category. The affective information category consisted of sentences which reflected the emotions and ideas of participants, their past experiences and traditions. Superficial information or daily 
life example categories include sentences that are used in daily life and lack any scientific meaning. The non-scientific or mis-conceptual information categories include sentences where participants attempted to include scientific meanings but confused the related concept with concepts of different and incorrect meanings.

\subsection{Validity and Reliability of the Study}

Two procedures were implemented in order to ensure the validity of the results within the study: coding of data and data analysis process [12, 24], and for each of the categories obtained during the study, examples were selected from the opinions of pre-service teachers deemed to have represented each respective category in the best manner and those examples were included in the findings section $[46,59,61]$.

In order to ensure the validity of this study, the codes of two researchers, one of whom is the author of this study, as well as the related categories were compared. This was done in order to determine whether or not the codes provided within the conceptual categories actually represented their respective conceptual categories. The consistency of the codes used by researchers independently from one another was determined by means of "Opinion unity" or "Opinion disunity" markings. Thus, the reliability of the data analysis was calculated by means of the following formula: [Opinion unity / (Opinion unity + Opinion disunity) x 100] [38]. The average reliability ratio amongst the coders in relation to the concept of light was found to be $85 \%$.

\section{Findings}

The words expressed by the pre-service teachers in relation to the concept of light, along with their frequencies are presented in Table 1.

It has been observed that the number of words expressed by the pre-service teachers in relation to the concept of light is limited, only 56 words in total. It has also been noted that most of the prospective teachers correlated the concept of light with the sun, stars, light bulb, illumination, energy, refraction of light, velocity of light, artificial light source, linear way, electricity, moon and lamp concepts.
Table 1. Words provided by primary school pre-service teachers about the concept of "light"

\begin{tabular}{|c|c|c|c|c|c|}
\hline $\begin{array}{c}\text { Words } \\
\text { expressed }\end{array}$ & $\mathrm{f}$ & $\begin{array}{c}\text { Words } \\
\text { expressed }\end{array}$ & $\mathrm{f}$ & Words expressed & $\mathrm{f}$ \\
\hline $\begin{array}{c}\text { Artificial } \\
\text { light source }\end{array}$ & 12 & Illumination & 5 & Photosynthesis & 3 \\
\hline Battery & 2 & Lamp & 10 & Planets & 2 \\
\hline Beam & 5 & Lens & 1 & Power & 4 \\
\hline Brightness & 2 & Light & 16 & Reflection & 5 \\
\hline Candle & 2 & Lightning & 1 & Shadow & 6 \\
\hline Circuit key & 1 & Light bulb & 17 & Simplifying life & 2 \\
\hline Color & 5 & Light current & 1 & Solar eclipse & 1 \\
\hline $\begin{array}{c}\text { Conducting } \\
\text { wire }\end{array}$ & 2 & $\begin{array}{c}\text { Light } \\
\text { refraction }\end{array}$ & 12 & Star & 20 \\
\hline Economy & 1 & Light source & 7 & Sun & 25 \\
\hline Edison & 4 & Light wave & 2 & $\begin{array}{c}\text { Transparent } \\
\text { substance }\end{array}$ & 5 \\
\hline Einstein & 1 & Light year & 2 & $\begin{array}{c}\text { Translucent } \\
\text { substance }\end{array}$ & 2 \\
\hline Electricity & 11 & Linear way & 11 & Technology & 2 \\
\hline $\begin{array}{c}\text { Electrical } \\
\text { circuit }\end{array}$ & 1 & Mirror & 1 & Umbra & 1 \\
\hline Energy & 15 & Moon & 10 & $\begin{array}{c}\text { Vehicle } \\
\text { headlight }\end{array}$ & 1 \\
\hline Eye & 6 & $\begin{array}{c}\text { Natural light } \\
\text { source }\end{array}$ & 8 & Vision & 4 \\
\hline Fire & 1 & Night and day & 8 & Yellow light & 2 \\
\hline Firefly & 5 & $\begin{array}{c}\text { Opaque } \\
\text { substance }\end{array}$ & 3 & Velocity of light & 12 \\
\hline Flashlight & 8 & Optics & 2 & & \\
\hline $\begin{array}{l}\text { Formation of } \\
\text { the rainbow }\end{array}$ & 5 & Penumbra & 1 & & \\
\hline The total co & & $\begin{array}{r}\text { rds which were } \\
\text { reached }\end{array}$ & & to the concept of & \\
\hline
\end{tabular}

The frequencies and distribution of the cognitive structures of the primary school pre-service teachers regarding the concept of "light" are presented in Table 2.

Apart from the majority of concepts associated by the pre-service teachers being noted as the source of light and the nature of light; the association of concepts such as circuit elements, relation to daily life, formation of image and scientists has also been observed. 
Table 2. The cognitive structures of the primary school pre-service teachers in regards to the concept of "light"

\begin{tabular}{|c|c|c|c|c|c|}
\hline Category & Concepts and frequency & Total & Category & Concepts and frequency & Total \\
\hline \multirow{7}{*}{$\begin{array}{l}\text { 1.Circuit } \\
\text { elements }\end{array}$} & Light bulb (17) & & \multirow{7}{*}{$\begin{array}{l}\text { 4. Relation to } \\
\text { daily life }\end{array}$} & Illumination (5) & \multirow{7}{*}{37} \\
\hline & Circuit key (1) & & & Light (16) & \\
\hline & Electricity (11) & & & Night and day (8) & \\
\hline & Electrical circuit (1) & 36 & & Photosynthesis (3) & \\
\hline & Conducting wire (2) & & & Simplifying life (2) & \\
\hline & Battery (2) & & & Economy (1) & \\
\hline & Brightness (2) & & & Technology (2) & \\
\hline \multirow{14}{*}{$\begin{array}{l}\text { 2. Source of } \\
\text { light }\end{array}$} & Vehicle headlight (1) & \multirow{14}{*}{112} & \multirow{14}{*}{ 5. Nature of light } & & \multirow{14}{*}{81} \\
\hline & Fire (1) & & & Linear way (11) & \\
\hline & Firefly (5) & & & Energy $(15)$ & \\
\hline & Moon (10) & & & Formation of the rainbow (5) & \\
\hline & Natural light source (8) & & & Power (4) & \\
\hline & Flashlight (8) & & & Light current (1) & \\
\hline & Planets (2) & & & Light refraction (12) & \\
\hline & Sun $(25)$ & & & Light wave (2) & \\
\hline & Light source (7) & & & Velocity of light (12) & \\
\hline & Lamp (10) & & & Light year (2) & \\
\hline & Candle (2) & & & Beam (5) & \\
\hline & & & & Color (5) & \\
\hline & $\begin{array}{l}\text { Lightning (1) } \\
\text { Artificial light source (12) }\end{array}$ & & & Yellow light (2) & \\
\hline & Star $(20)$ & & & Reflection (5) & \\
\hline \multirow{12}{*}{$\begin{array}{l}\text { 3. Formation of } \\
\text { image }\end{array}$} & Mirror (1) & \multirow{12}{*}{33} & \multirow{12}{*}{ 6. Scientists } & & \multirow{12}{*}{5} \\
\hline & Shadow (6) & & & & \\
\hline & Vision (4) & & & & \\
\hline & Eye (6) & & & & \\
\hline & Solar eclipse (1) & & & & \\
\hline & Lens (1) & & & Edison (4) & \\
\hline & Opaque substance (3) & & & Einstein (1) & \\
\hline & Optics $(2)$ & & & & \\
\hline & Transparent substance (5) & & & & \\
\hline & Translucent substance (2) & & & & \\
\hline & Umbra (1) & & & & \\
\hline & Penumbra (1) & & & & \\
\hline
\end{tabular}

The words that evoked in the pre-service teachers' minds when encountered with the concept of light are presented in Figure 1.

The distribution of sentences submitted by each of the primary school pre-service teachers in relation to the concept of "light" by category, as well as several examples are presented in Table 3.

Table 3. Categories of sentences submitted by primary school pre-service teachers in relation to the concept of light

\begin{tabular}{|c|c|c|}
\hline Category & Sample sentence & $\mathrm{f}$ \\
\hline $\begin{array}{l}\text { Correct scientific } \\
\text { information }\end{array}$ & $\begin{array}{l}\text { Light is an energy that emanates from its source and follows a linear path. } \\
\text { There are artificial and natural sources of light. } \\
\text { Sun, star, firefly are natural sources of light; flashlight, candle, light bulb, fluorescent } \\
\text { lamps are artificial sources of light. } \\
\text { A rainbow is formed by the refraction of sunlight. } \\
\text { Photosynthesis cannot occur without light. } \\
\text { Light travels faster than sound and is the fastest traveling energy. } \\
\text { - } \quad \text { ight in an electrical circuit is the energy emitted by the light bulb. } \\
\text { Materials that allow light to pass are transparent, materials that do not let the light pass } \\
\text { are nontransparent (opaque) materials. }\end{array}$ & 45 \\
\hline $\begin{array}{l}\text { Affective } \\
\text { information }\end{array}$ & $\begin{array}{l}\text { In a dark environment we need light. } \\
\text { The most important source of light is the sun. } \\
\text { Light simplifies our lives. } \\
\text { Lamps help us meet our light requirements in our daily lives. }\end{array}$ & 6 \\
\hline $\begin{array}{l}\text { Information } \\
\text { containing } \\
\text { superficial or } \\
\text { daily life } \\
\text { examples }\end{array}$ & $\begin{array}{l}\text { Light enables us to see objects. } \\
\text { A flashlight is a manmade artificial light source. } \\
\text { Colors are formed with the help of light. } \\
\text { Light enables us to see each other and other objects during the night. } \\
\text { Every light has its source } \\
\text { When the light hits an object a shadow is formed. }\end{array}$ & 19 \\
\hline $\begin{array}{l}\text { Non-scientific } \\
\text { information or } \\
\text { information } \\
\text { containing } \\
\text { misconceptions }\end{array}$ & $\begin{array}{l}\text { Reflects the light from objects. } \\
\text { Unit of distance in space. } \\
\text { Light enables us to see by directly hitting our eyes. } \\
\text { Light is conducted by means of conductive wires. } \\
\text { A source that follows a linear path and has a certain velocity. } \\
\text { Light travels at different velocity depending on its source. } \\
\text { Stars attain their brightness and light from the sun. } \\
\text { The moon is a natural source of light. } \\
\text { Stars are an artificial source of light. } \\
\text { Light is illumination. } \\
\text { A visible energy source. } \\
\text { Light converts electrical power into energy through a light bulb and is then distributed } \\
\text { throughout the environment. } \\
\text { A substance which travels on a linear path from a certain source without any affecting } \\
\text { factors. }\end{array}$ & 18 \\
\hline
\end{tabular}




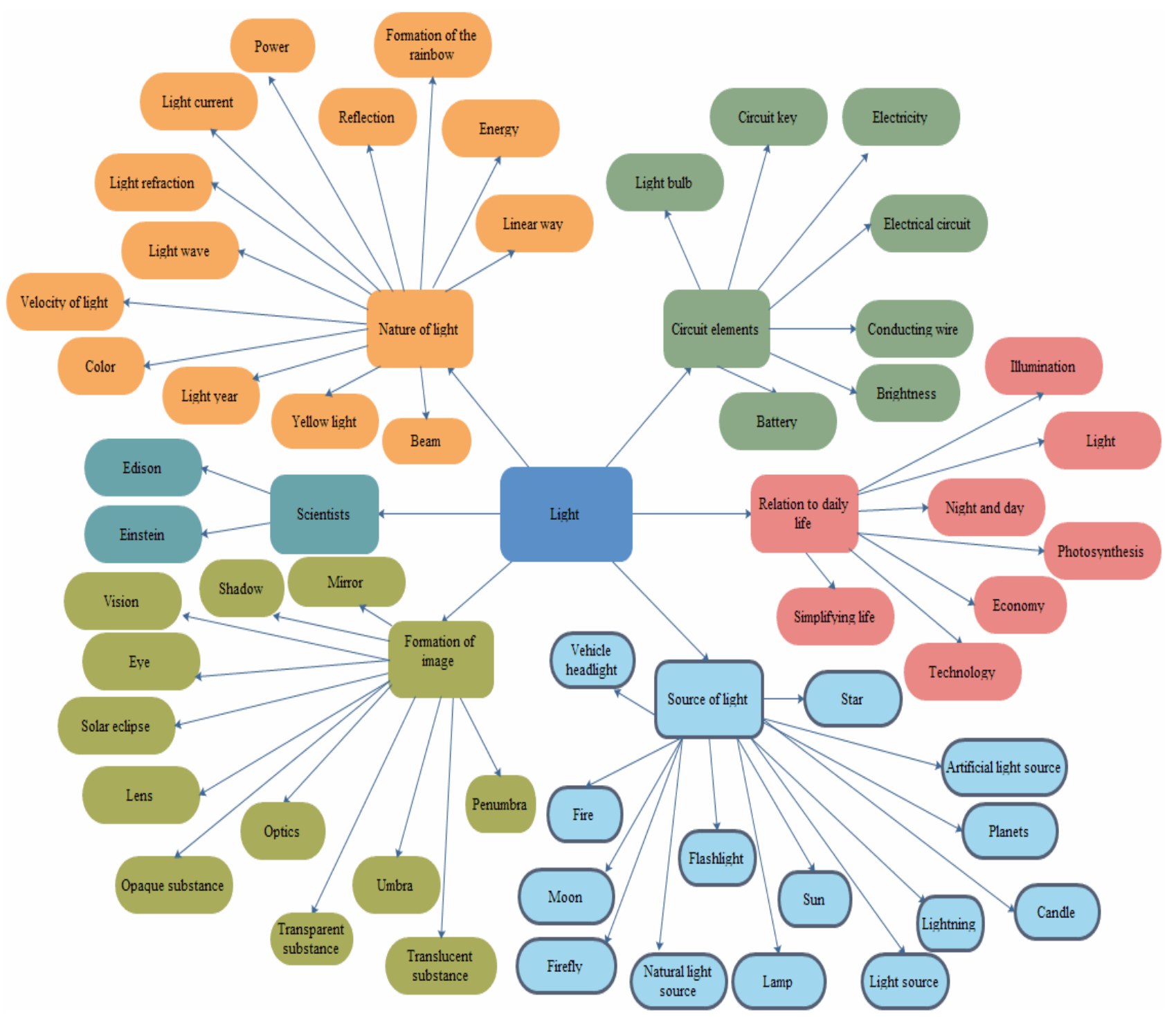

Figure 1. The words associated by the pre-service teachers in regards to the concept of light

Once each of the sentences formed by the pre-service teachers is examined, the correct scientific information category contains the general expressions such as light is a type of energy, has a certain source, light sources can be distinguished as natural and artificial, as well as light following a linear path. It has also been observed that this category includes sentences like light is necessary for the occurrence of photosynthesis, that a rainbow is formed by the refraction of light, transparent and non-transparent materials and about the velocity of light. The affective information category reveals that the meanings attributed to light revolve the fact that light is needed in a dark environment (room), that light aids in simplifying our lives, as well as answers which state that the sun is our most important source of light. In addition, in the superficial and daily life category, the expressions mostly revolve around vision, illumination, shadow, color and artificial light sources (flashlight). The non-scientific information and misconception category includes statements regarding the vision process, the equivalence of light and light source, the sun's being the only natural source of light and the perception of light as a unit for distance (within the scope of astronomy concepts - light year, etc.)

\section{Discussion and Conclusion}

This study attempted to reveal in a general manner the concepts relating to the concept of light within the cognitive structures of pre-service teachers by means of the word association test. The word association test may not be able to disclose whether the pre-service teachers completely understand the concept of light. However, it is believed necessary to reveal the notion that reflects on the present situation in regards to the cognitive structures of the pre-service teachers, in relation to the concept of light. Due to the fact that there are obvious misconceptions and alternative concepts present in the cognitive structures of the 
pre-service teachers, there may be future prevention in teaching the concept of light. Therefore, the word association test can be utilized as a beneficial and helpful tool for the evaluation of cognitive structures of the pre-service teachers, allowing the formation of concepts to be considered as meaningful connections or not in terms of certain key concepts $[3,4,5,39]$.

During this study it was found that the pre-service teachers generally had a limited number of concepts in their minds in regards to the concept of light, some of which are as follows: the sun, stars, light bulb, illumination, energy, light refraction, velocity of light, artificial light source, linear path, electricity, moon and lamp concepts. Apart from the majority of concepts associated by the pre-service teachers being related to the source and nature of light; the association of concepts such as circuit elements, relation to daily life, formation of image and the relation to scientists has also been observed.

In addition, each of the sentences that have been formed by the pre-service teachers are generally within the correct scientific information category, along with sentences about superficial or daily life, non-scientific or misunderstood information and the affective information categories. It has also been discovered that the pre-service teachers mostly exhibited correct scientific knowledge by such phrases as "the light is a type of energy", "the energy emitted by a light bulb in an electrical circuit", "follows a linear path", "the light has a source", "light sources can be natural and artificial", "light is necessary in order for photosynthesis to occur", "rainbows are formed by refraction of the light", "there are translucent and non-translucent materials", and that "light travels faster than the sound".

Moreover, within the affective information category, the pre-service teachers associated the concept of light with a variety of simplistic notions such as; "the light is needed in a dark environment" and "light simplifies our lives". Among the examples of sentences which were submitted by the pre-service teachers within the superficial and daily life category were stated as "seeing objects, illuminating the environment, shadow, color and artificial light sources". Aside from the fact that the pre-service teachers have a superficial frame of knowledge in regards to the concept of light, it has also been noted that this kind of information contains various misconceptions. Cansungu [9] (2000) indicates in his study that the acquisition of incorrect concepts in relation to the concept of light is contributed by daily life experiences. In this context, it is noted that the scientific knowledge acquired by the pre-service teachers in regards to the concept of light during their education process, is reinforced by the notion of daily life [42].

From the sentences submitted by each of the pre-service teachers, it was determined that their misconceptions resulted in the notion of light and light sources, the concept that light is a source of energy, and that light is a source of visible energy. Cansungu-Koray \& Bal [10] (2002) found during their research that 5 th and 6 th grade students held the misunderstandings of "light being a source that illumines its surroundings" as well as the "energy dispersing from light sources being the light itself". Unal-Coban [56] (2009) discovered the misconception amongst 7 th grade students that all types of light are visible to the human eye.

Another section of pre-service teachers also consider the sun to be the single natural source of light, or the sun to be a natural source of light whilst the stars remain artificial sources of light and only receive their light from the sun. Uzoglu, Yildiz, Demir \& Buyukkasap [57] (2013) found that a range of science teachers held the alternative concept that "stars are not visible during the day because they only reflect the moonlight".

Misconceptions such as "light is the same as illumination and light is an object" were also encountered during the study. Yildiz [60] (2000) established during their study that 6th grade primary school students attained the misconception that "light is an illuminating substance or object", "light is an effect that enables us to see" and "light is the same as illumination". Kaya [26] (2010) found in their study that science pre-service teachers also held the misunderstanding that "light is a matter that illuminates the objects it reaches". Guesne, Driver \& Tiberghien [20] (1985) derived from their study which was conducted with 13-14 year old students that they generally perceived light as a substance.

Although the portion is small, some of the pre-service teachers still considered the light to have different velocity depending on its sources wrongly. Also, Buyukkasap, Duzgun \& Ertugrul [6] (2001) noted during their studies that high school students had the misconception that light had various velocities depending on its sources.

In addition, it was declared that the pre-service teachers assumed wrongly that light and electricity were the same and light is created by the means of conductive wires; however, the fact is the electrical power of light is converted into energy in the light bulb and emitted into the environment. This misconception has also been supported by the connection formed by the pre-service teachers in regards to the concept of light and electrical circuit elements. Cansungu-Koray \& Bal [10] (2002) found in their study that 5 th and 6 th grade students held misconceptions regarding the fact that light is a type of electrical source which enables us to see the environment. This specific situation requires the misunderstanding within the cognitive structure of pre-service teachers to be modified with the correct scientific information, as well as the learning process to be planned and executed in accordance with this information. In saying this, the act of determining the cognitive structures of the pre-service teachers, prior to their education, will assist the teachers in training to select the appropriate teaching strategies for their future students [55]. Furthermore, the development of effective training materials, which will contain various activities and experiences, will enable the pre-service teachers in training to utilize the chosen teaching strategy for each procedure. This will ensure that the modification of the misconceptions within the cognitive structures of the pre-service teachers will be correctly updated to scientific information, thus, develop their 
cognitive structures.

\section{REFERENCES}

[1] Akdeniz, A.R., Yildiz, I. \& Yigit, N. (2001). Ilkogretim 6. sinif ogrencilerinin isik unitesindeki kavram yanilgilari. Cukurova Universitesi Egitim Fakultesi Dergisi, 2(20), 72-78.

[2] Aydin, F. \& Tasar, M.F. (2010). An Investigation of pre-service science teachers' cognitive structures and ideas about the nature of technology. Ahi Evran Universitesi Kirsehir Egitim Fakultesi Dergisi,11(4), 209-221.

[3] Bahar, M., Johnstone, A.H. \& Sutcliffe, R.G. (1999). Investigation of students' cognitive structure in elementary genetics through word association tests. Journal of Biological Education, 33,134-141.

[4] Bahar, M. \& Ozatli, N.S. (2003). Kelime iletisim test yontemi ile lise 1. sinif ogrencilerinin canlilarin temel bilesenleri konusundaki bilissel yapilarinin arastirilmasi. Balikesir Universitesi Fen Bilimleri Enstitusu Dergisi, 5(2), 75-85.

[5] Bahar, M., Nartgun, Z., Durmus, S. \& Bicak, B. (2006) Geleneksel-alternatif olcme ve degerlendirme teknikleri ogretmen el kitabi. Ankara: Pegem A Yayincilik.

[6] Buyukkasap, E., Duzgun, B. \& Ertugrul, M. (2001). Lise ogrencilerinin isik hakkindaki yanlis kavramlari. Milli Egitim Dergisi, 141, 32-35.

[7] Cachapuz, A.F.C. \& Maskill, R. (1987). Detecting changes with learning in the organization of knowledge: use of word association tests to follow the learning of collision theory. International Journal of Science Education, 9, 491-504.

[8] Cachapuz, A.F.C. \& Maskill, R. (1989). Using word association in formative classroom tests: following the learning of Le Chatelier's principle. International Journal of Science Education, 11(2), 235-246.

[9] Cansungu, O. (2000). Ilkogretim ogrencilerinin (5., 6. ve 7. siniflar) isik ve isikla ilgili kavramlari algilama sekillerinin tespiti uzerine bir arastirma. Yayimlanmamis yuksek lisans tezi, Gazi Universitesi, Egitim Bilimleri Enstitusu, Ankara.

[10] Cansungu-Koray, O. \& Bal, S. (2002). Ilkogretim 5. ve 6. sinif ogrencilerinin isik ve isigin hizi ile ilgili yanlis kavramlari ve bu kavramlari olusturma sekilleri, Gazi Universitesi Gazi Egitim Fakultesi Dergisi, 22(1), 1-11.

[11] Cardellini, L. \& Bahar, M. (2000). Monitoring the learning of chemistry through word association tests. Australian Chemistry Resource Book, 19, 59-69.

[12] Daymon, C. \& Holloway, I. (2003). Qualitative research methods in public relations and marketing communications. London: Rout ledge.

[13] Derman, A. \& Eilks, I. (2016). Using a word association test for the assessment of high school students' cognitive structures on dissolution. Chemistry Education Research and Practice. Retrieved 12 August 2016 from http://pubs.rsc.org/en/content/articlelanding/2016/rp/c6rp000 84c\#!divRelatedContent
[14] Ekici, G. \& Kurt, H. (2014). Ogretmen adaylarinin "aids" kavrami konusundaki bilissel yapilari: bagimsiz kelime iliskilendirme testi ornegi, Turkiye Sosyal Arastirmalar Dergisi, 183, 267-306.

[15] Ekici, G., Gokmen, A. \& Kurt, H. (2014). Ogretmen adaylarinin "bilgisayar" kavrami konusundaki bilissel yapilarinin belirlenmesi. Gazi Universitesi Gazi Egitim Fakultesi Dergisi, 34(3), 359-405.

[16] Ercan, F., Tasdere, A. \& Ercan, N. (2010). Observation of cognitive structure and conceptual changes through word association tests. Journal of Turkish Science Education,7(2), 136-154.

[17] Eren, F., Sahin, I., Celik, I. \& Akturk, A.O. (2014). Analysis of secondary school students' perceptions about information technologies through a word association test, International Journal of Social, Management, Economics and Business Engineering, 8(8), 2512-2515.

[18] Gilbert, J.K., Boulter, C. \& Rutherford, M. (1998a). Models in explanations, part 1, horses for courses? International Journal of Science Education,20, 83-97.

[19] Gilbert, J.K., Boulter, C. \& Rutherford, M. (1998b). Models in explanations, part 2, whose voice? whose ears? International Journal of Science Education,20, 187-203.

[20] Guesne, E. (1985). Light. In Driver, R., Guesne, E. \& Tiberghien, A. (Eds.). Children's ideas in science. (pp. 10-32). Milton Keynes, UK: Open University Press.

[21] Gunes, H. \& Gozum, A.I.C. (2013). Ilkogretimde islenen ekoloji konusunun 10. sinif ogrencilerin ekosistem ekolojisi konusundaki hazirbulunusluk duzeyleri uzerindeki etkisinin saptanmasinda kelime iliskilendirmenin kullanilmasi. Egitim ve Ogretim Arastirmalari Dergisi, 2(3), 252-264.

[22] Gussarsky, E. \& Gorodetsky, M. (1990). On the concept "chemical equilibrium: the associative framework. Journal of Research in Science Teaching, 27(3), 197-204.

[23] Hovardas, T. \& Korfiatis, K.J. (2006). Word associations as a tool for assessing conceptual change in science education. Learning and Instruction, 16, 416-432.

[24] Hruschka, D.J., Schwartz, D., St. John, D.C., Picone-Decaro, E., Jenkins, R.A. \& Carey, J.W. (2004). Reliability in coding openended data: lessons learned from HIV behavioral research. Field Methods, 16(3), 307-331.

[25] Kara, I., Erduran-Avci, D. \& Cekbas, Y. (2008). Fen bilgisi ogretmen adaylarinin isik kavrami ile ilgili bilgi duzeylerinin arastirilmasi. Mehmet Akif Ersoy Universitesi Egitim Fakultesi Dergisi, 8(16), 46-57.

[26] Kaya, A. (2010). Fen bilgisi ogretmen adaylarinin isik ve atom kavramlarini anlama seviyelerinin tespiti, Erzincan Egitim Fakultesi Dergisi, 12(1), 15-37.

[27] Kaya, B. \& Akis, A. (2015). Cografya ogrencilerinin "hava" kavramiyla ilgili bilissel yapilarinin kelime iliskilendirme testi ile belirlenmesi. Turkish Studies, International Periodical for the Languages, Literature and History of Turkish or Turkic, 10(7), 557-574.

[28] Keskin, E. \& Orgun, E. (2015). Kelime iliskilendirme testi araciligiyla surdurulebilir turizm olgusunun kavramsal analizi: urgup ornegi. Journal of Tourism and Gastronomy Studies, 3(1), 30-40. 
[29] Kirtak-Ad, V.N. \& Demirci, N. (2012). Ogretmen adaylarinin cevre sorunlarini bilim dallari ve termodinamik yasalari ile iliskilendirme duzeyleri, Ahi Evran Universitesi Kirsehir Egitim Fakultesi Dergisi, 13(3),19-46.

[30] Kostova, Z. \& Radoynovska, B. (2008). Word association test for studying conceptual structures of teachers and students. Bulgarian Journal of Science and Education Policy, 2(2), 209-231.

[31] Kostova, Z. \& Radoynovska, B. (2010). Motivating students' learning using word association test and concept maps. Bulgarian Journal of Science and Education Policy, 4(1), 62-98.

[32] Kurt, H. (2013a). Turkish student biology teachers' conceptual structures and semantic attitudes towards microbes. Journal of Baltic Science Education,12(5), 608-639.

[33] Kurt, H. (2013b). Determining biology teacher candidates' conceptual structures about energy and attitudes towards energy. Journal of Baltic Science Education,12(4), 399-423.

[34] Kurt, H. \& Ekici, G. (2013a). What is a virus? Prospective biology teachers' cognitive structure on the concept of virus. International Online Journal of Educational Sciences, 5(3), 736-756.

[35] Kurt, H. \& Ekici, G. (2013b). Biyoloji ogretmen adaylarinin bagimsiz kelime iliskilendirme testi ve cizme-yazma teknigiyle "osmoz" kavrami konusundaki bilissel yapilarinin belirlenmesi. Turkish Studies, International Periodical for the Languages, Literature and History of Turkish or Turkic,8(12), 809-829.

[36] Lee, K-W. (1988). Two non-traditional measures of chemistry learning: Word association and idea association. Research in Science Education, 18(1), 169-176.

[37] Maskill, R. \& Cachapuz, A.F.C. (1989). Learning about the chemistry topic of equilibrium: the use of word association tests to detect developing conceptualizations. International Journal of Science Education, 11(1), 57-69.

[38] Miles, M.B. \& Huberman, A.M. (1994). Qualitative data analysis (2nd edition). Thousand Oaks, CA: Sage Publications.

[39] Nakiboglu, C. (2008). Using word associations for assessing nonmajor science students' knowledge structure before and after general chemistry instructions: the case of atomic structure. Chemical Educational Research Practice, 9, 309-322.

[40] Onel, A. \& Yuce, Z. (2016). Determining the cognitive structures of science teacher candidates on "evolution" through word association test. Journal of Educational Sciences Research, 6(1), 23-39.

[41] Ozatli, N.S. \& Bahar, M. (2010). Ogrencilerin bosaltim sistemi konusundaki bilissel yapilarinin yeni teknikler ile ortaya konmasi. Abant Izzet Baysal Universitesi Dergisi, $10(2), 9-26$

[42] Ozata-Yucel, E. \& Ozkan, M. (2015). Determination of secondary school students' cognitive structure, and misconception in ecological concepts through word association test. Educational Research and Reviews, 10(5), 660-674.
[43] Polat, G. (2013). 9. sinif ogrencilerinin cevreye iliskin bilissel yapilarinin kelime iliskilendirme test teknigi ile tespiti. Necatibey Egitim Fakultesi Elektronik Fen ve Matematik Egitimi Dergisi, 7(1), 97-120.

[44] Posner, G. J., Strike, K. A., Hewson, P. W. \& Gertzog, W. A. (1982). Accommodation of a scientific conception: Toward a theory of conceptual change. Science Education, 66(2), 211-227.

[45] Ramadas, J. \& Driver, R. (1989). Aspects of secondary students' ideas about light. Children's Learning in Science Project, CSSME University of Leeds.

[46] Roberts, P. \& Priest, H. (2006). Reliability and validity in research. Nursing Standard,20, 41-45.

[47] Sato, M. \& James, P. (1999). "Nature" and "Environment" as perceived by university students and their supervisors. International Journal of Environmental Education and Information, 18(2), 165-172.

[48] Sen, A.I. (2003). Ilkogretim ogrencilerinin isik, gorme ve aynalar konusundaki kavram yanilgilarinin ve ogrenme zorluklarinin incelenmesi. Hacettepe Universitesi Egitim Fakultesi Dergisi, 25, 176-185.

[49] Shavelson, R.J. (1974). Some methods for examining content structure and cognitive structure in mathematics instruction. Paper presented at the annual meeting of the American Educational Research Association, Chicago, Illinoisg, April.

[50] Simsek, M. (2013). Sosyal bilgiler ogretmen adaylarinin cografi bilgi sistemleri (cbs) konusundaki bilissel yapilarinin ve alternatif kavramlarinin kelime iliskilendirmesi testi ile belirlenmesi. Researcher: Social Science Studies, 1, 65-75.

[51] Tasdemir, A. \& Demirbas, M. (2010). Ilkogretim ogrencilerinin fen ve teknoloji dersinde gordukleri konulardaki kavramları gunluk yasamla iliskilendirebilme duzeyleri. Uluslararası Insan Bilimleri Dergisi, 7(1), 124-148.

[52] Tasdere, A., Ozsevgec, T. \& Turkmen, L. (2014). Bilimin dogasina yönelik tamamlayıcı bir olcme araci: kelime iliskilendirme testi. Fen Egitimi ve Arastirmalari Dernegi, Fen Bilimleri Ogretimi Dergisi, 2(2), 129-144.

[53] Timur, S. (2012). Examining cognitive structures of prospective preschool teachers concerning the subject "force and motion". Educational Sciences: Theory \& Practice, Special Issue, 3039-3049.

[54] Tsai, C-C. (2001). Probing students' cognitive structures in science: the use of a flow map method coupled with a meta-listening technique. Studies in Educational Evaluation, 27, 257-268.

[55] Tsai, C-C. \& Huang, C-M. (2002). Exploring students' cognitive structures in learning science: a review of relevant methods. Journal of Biological Education, 36(4), 163-169.

[56] Unal-Coban, G. (2009). Modellemeye dayali fen ogretiminin ogrencilerin kavramsal anlama duzeylerine, bilimsel surec becerilerine, bilimsel bilgi ve varlik anlayislarina etkisi: 7 . sinif isik unitesi ornegi. Yayimlanmamis doktora tezi, Dokuz Eylul Universitesi, İzmir.

[57] Uzoglu, M., Yildiz, A., Demir, Y. \& Buyukkasap, E. (2013). Fen bilgisi ogretmen adaylarinin isikla ilgili kavram yanilgilarinin belirlenmesinde kavram karikaturlerinin ve acik uclu sorularin etkililiklerinin karsilastirilmasi. Ahi Evran Universitesi Kirsehir Egitim Fakultesi Dergisi, 14(1), 367-388. 
[58] Uzun, S., Alev, N. \& Karal, I.S. (2013). A cross-age study of an understanding of light and sight concepts in physics. Science Education International, 24(2), 129-149.

[59] Wiersma, W. \& Jurs, S.G. (2005). Research methods in education: an introduction. Needham Heights, MA: Allyn \& Bacon.
[60] Yildiz, G. (2000). Ilkogretim 6. sinif ogrencilerinin isik unitesindeki kavram yanilgilari. Yayimlanmamis yuksek lisans tezi, Karadeniz Teknik Universitesi, Fen Bilimleri Enstitusu, Trabzon.

[61] Yildirim, A. \& Simsek, H. (2011). Sosyal bilimlerde nitel arastirma yontemleri. Ankara: Seckin Yayincilik. 